\title{
Tectono-thermal Evolution of the Lower Paleozoic Petroleum Source Rocks in the Southern Lublin Trough: Implications for Shale Gas Exploration from Maturity Modelling
}

\author{
Dariusz Botor ${ }^{1, *}$ \\ ${ }^{1}$ AGH University of Science and Technology, Faculty of Geology, Geophysics and Environmental \\ Protection, A. Mickiewicza Av. 30, 30-059 Krakow, Poland
}

\begin{abstract}
The Lower Paleozoic basins of eastern Poland have recently been the focus of intensive exploration for shale gas. In the Lublin Basin potential unconventional play is related to Lower Silurian source rocks. In order to assess petroleum charge history of these shale gas reservoirs, 1-D maturity modeling has been performed. In the Łopiennik IG-1 well, which is the only well that penetrated Lower Paleozoic strata in the study area, the uniform vitrinite reflectance values within the Paleozoic section are interpreted as being mainly the result of higher heat flow in the Late Carboniferous to Early Permian times and $\sim 3500 \mathrm{~m}$ thick overburden eroded due to the Variscan inversion. Moreover, our model has been supported by zircon helium and apatite fission track dating. The Lower Paleozoic strata in the study area reached maximum temperature in the Late Carboniferous time. Accomplished tectono-thermal model allowed establishing that petroleum generation in the Lower Silurian source rocks developed mainly in the Devonian Carboniferous period. Whereas, during Mesozoic burial, hydrocarbon generation processes did not develop again. This has negative influence on potential durability of shale gas reservoirs. Key words - maturity modelling, shale gas, Lublin Trough.
\end{abstract}

\section{Introduction}

The Lower Paleozoic basins of eastern Poland have recently been the focus of intensive exploration for shale gas. The characteristic feature of these basins is an exceptionally high volumetric contribution of mudstone and claystone, being up to 1000-2000 m thick [1-3]. However, within this section there are a few individual shale formations (in the Upper Cambrian, Upper Ordovician and Lower Silurian) identified, which are characterized by elevated organic carbon contents $(\sim 1-2 \%$ wt. total organic carbon, TOC) and shale gas/oil potential [4]. Kerogen is mostly low-Sulphur II type-oil prone in the Lower Paleozoic sediments of the SW slope of the East European Craton [2, 5, 6].

In the Lublin Basin potential unconventional play is exclusively related to the Lower Silurian (Wenlock) source rocks, within interval of no more than approximately $100 \mathrm{~m}$ [4].

* Corresponding author: botor@agh.edu.pl 
However, the Lublin Basin was subjected to tectonic inversion during the late Carboniferous (late Variscan) compressional tectonic deformations in Late Carboniferous [7, 8].

A characteristic long time gap in sedimentary record occurs between Jurassic and late Carboniferous or Devonian time caused mainly by erosional processes. It is related to Variscan inversion, which is not well constrained $[8,9]$, consequently timing of hydrocarbon generation and migration is disputable. In order to assess burial and thermal history of Lower Paleozoic shale gas reservoirs, 1-D maturity modeling has been performed in the Łopiennik IG-1 well, which is the only well that penetrated Lower Paleozoic strata in southern part of study area (Fig. 1).

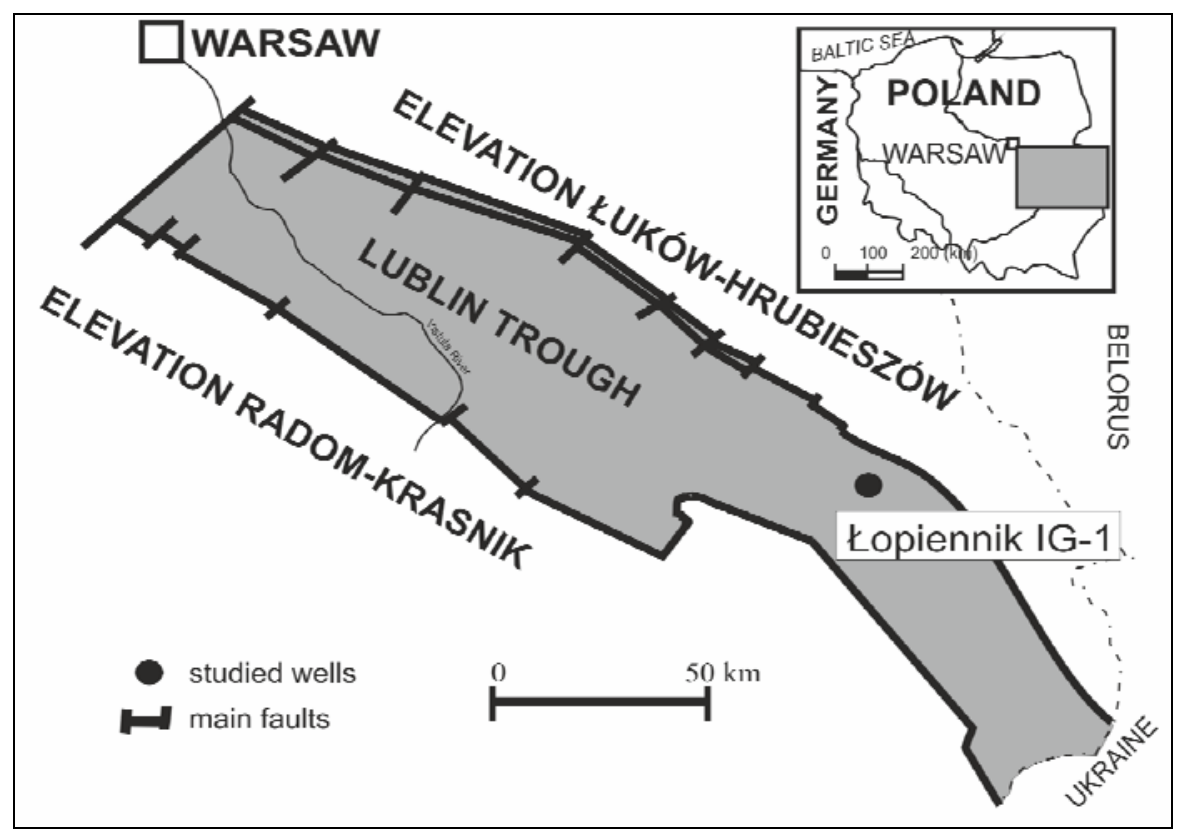

Fig. 1. Simplified map of the study area and location of the Łopiennik IG-1 well

\section{Geological setting}

The study area is situated at the south-western margin of the Precambrian East-European Craton at its contact with the Paleozoic Central-European units. The SW limit of the EastEuropean Craton is conventionally defined in Poland by the Teisseyre-Tornquist Zone that represents the longest European tectonic lineament [1, 8]. Although the formation of the Lublin Trough took place between the Devonian and Early Carboniferous, its main framework is of latest Carboniferous age [7]. The Lublin Trough was tectonically inverted during late Carboniferous (Variscan) event. In the central Lublin area, the Carboniferous coal-bearing siliciclastic section begins with Visean volcanogenic rocks. The Carboniferous strata ( up to $2000 \mathrm{~m}$ in thickness) rest unconformably on Devonian, Silurian, Ordovician and Cambrian rocks in various parts of the basin. The pre-Carboniferous substratum includes mostly clastic Lower Paleozoic ( 750-2500 $\mathrm{m}$ in thickness) and Lower Devonian strata (500-2300 m) as well as Middle and Upper Devonian carbonates ( 700-3000 m) [1, 7-9]. Not much is known about the distribution of Lower Paleozoic strata in the Lublin Trough because it has only been penetrated by a few deep wells $[1,7,9]$. The Lower Paleozoic section is composed of the Cambrian strata, represented by deformed coarse-grained sediments (mainly conglomerates and arkoses), laterally passing into mudstones usually a few hundred meters thick; the 
Ordovician carbonate and clastic complex, usually less than a hundred metres thick; and the Silurian mainly fine-grained claystone and siltstone sequence, up to $1500 \mathrm{~m}$ thick. The Paleozoic fill is overlain by $400-1000 \mathrm{~m}$ of Mesozoic (mainly Cretaceous) and Quaternary strata $[1,7-9]$.

\section{Methods}

Detailed description of applied numerical maturity modelling have been presented elsewhere [e.g. 10]. In this work, 1-D maturity modelling was carried out using PetroMod software (ver. 11) developed by Schlumberger. Integrated numerical modelling (one-dimensional, 1-D) was used to reconstruct the geological evolution of the study area and hence to derive the history of petroleum generation. The modelling procedure employed data defining the burial history, comprising the stratigraphy, thickness and lithology of the distinguished intervals as well as petrophysical parameters of rocks, the contemporary thermal regime and the present thermal maturity of organic matter. Thermal maturity has been calculated using the "Easy\%Ro" algorithm [11]. Basic input parameters for modeling were taken from well data. The published present-day well temperature, porosity, density, mean vitrinite reflectance were used for verification of reliability and calibration of the calculated 1-D thermal models [12]. The thickness of the removed part of the Upper Paleozoic sediments was calculated taking into account thermal maturity, porosity and density data [12]. In the Devonian and younger sediments vitrinite reflectance has been measured, whereas in the Lower Paleozoic sediments measurements has been performed on vitrinite-like organic particle, which are not true vitrinite, but mainly graptolites [12]. Therefore, such measurements are regarded as organoclast reflectance [12]. However, recent studies has shown that such measurements are comparable to vitrinite reflectance [13].

\section{Results and discussion}

The Lublin Basin is characterized by very complex early to late Paleozoic geological evolution [7-9]. The burial history curves in the Łopiennik IG-1 well show generally continuous Neoproterozoic to Devonian sedimentation (Fig. 2). It was subjected to a very intense latest Devonian/ Early Carboniferous (Bretonian phase), mostly reverse faulting and block uplift related to reactivation of the Precambrian fault zones during this tectonic phase. These tectonic movements might have been genetically linked to widespread tectonic activity within the East European Craton plate farther to the east, e.g. in the Prypiat Graben [e.g. 7].

The Lublin Basin was inverted during the late Carboniferous compressional tectonic deformations $[7,8]$. It can be correlated with the main phase of orogenic activity within the Variscan fold-and-thrust belt. During this tectonic phase complex system of thin-skinned compressional structures was formed [8]. A characteristic feature is the very rapid subsidence throughout the Late Carboniferous period. By the end of the Carboniferous, the vast majority of the total subsidence had occurred, and hence maximum burial and maximum temperature occurred in the latest Carboniferous just before the major tectonic inversion (Fig. 2). Paleozoic strata are covered by Jurassic and Cretaceous sediments, which were deposited in the NE flank of Mid-Polish Trough, which was finally inverted during late Cretaceous - Paleogene times (Fig. 2).

In the Łopiennik IG-1 well, the fairly uniform vitrinite reflectance values with in the Paleozoic section are interpreted as being mainly a result of higher heat flow in Late Carboniferous to Early Permian times and $\sim 3500$ m Carboniferous overburden eroded due to late Carboniferous inversion (Figs. 2-3). Although, there is no organic maturity data from the Jurassic-Cretaceous of this section, but Mesozoic profiles in adjacent area show low 
maturity, around $0.5 \%$ mean vitrinite reflectance. Moreover, this model has been recently supported by zircon helium and apatite fission track dating [14]. Thermal maturity development of the Wenlock source rocks is related mainly to Devonian and Carboniferous burial (Fig. 4).

General, hydrocarbon generation is controlled by organic matter quality and thermal history of the source rock. In terms of hydrocarbon generation, the critical period in the evolution of a sedimentary basin is the time of maximum burial, which occurred in the Late Carboniferous in the study area, that is documented by zircon helium and apatite fission track dating [14] (Fig. 2). The Carboniferous burial occurred in a higher than present-day heat flow regime, which can be explained by Early Carboniferous volcanism associated with Variscan tectonism, which was also pointed by many authors working in this area [e.g. 15]. This could have had a significant thermal effect for tens of million years if it was associated with deep heat sources. Therefore, in the Lower Paleozoic strata of the study area maximum temperature occurred in the Late Carboniferous period.

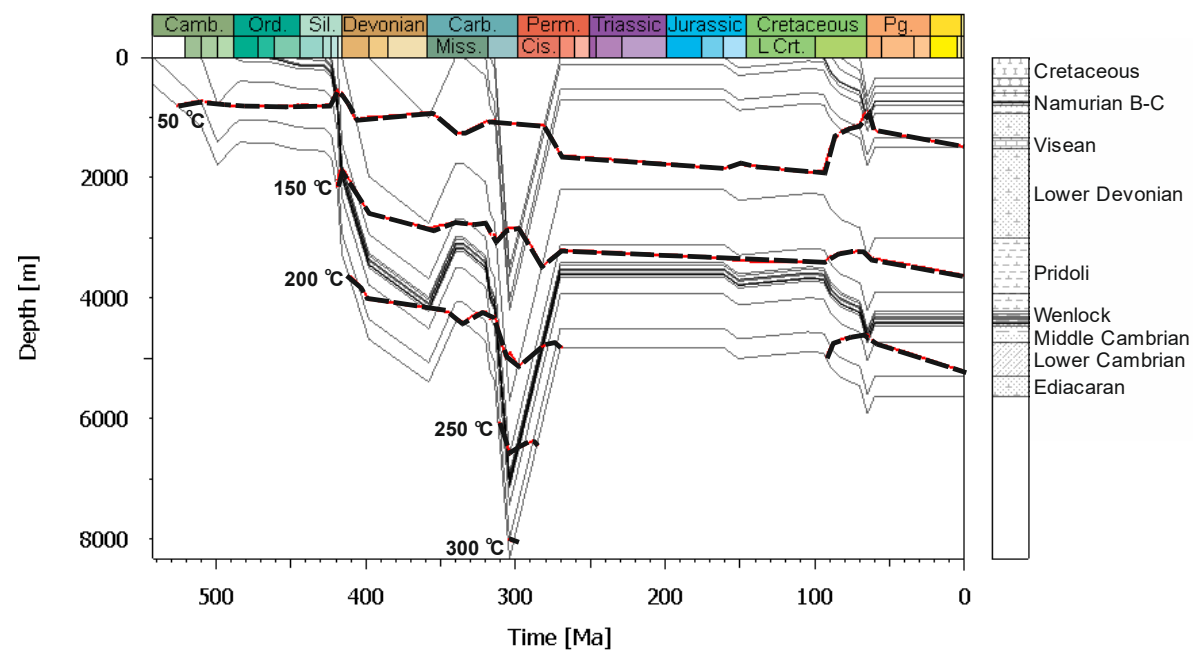

Fig. 2. Burial and thermal history model for the Łopiennik IG-1 well, assuming $3500 \mathrm{~m}$ of eroded Upper Carboniferous sediments and heat flow of $60 \mathrm{~mW} / \mathrm{m} 2$ during maximum burial in the Late Carboniferous

A

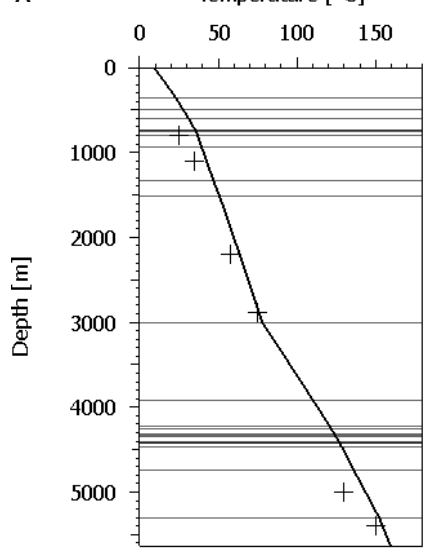

B Vitrinite Reflectance [\%Ro]
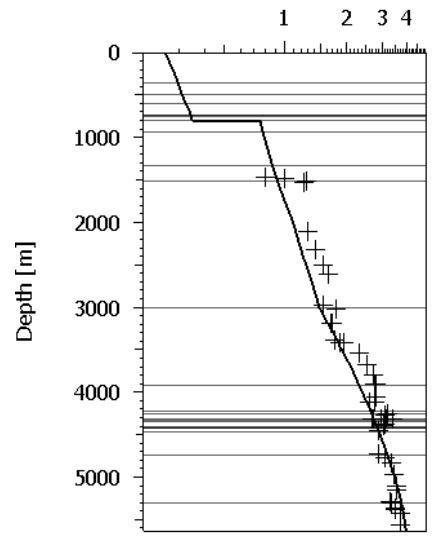

Fig. 3. Model calibration in the Łopiennik IG-1 well by means of present-day BHT temperature (A) and thermal maturity in the vitrinite reflectance scale (B) 


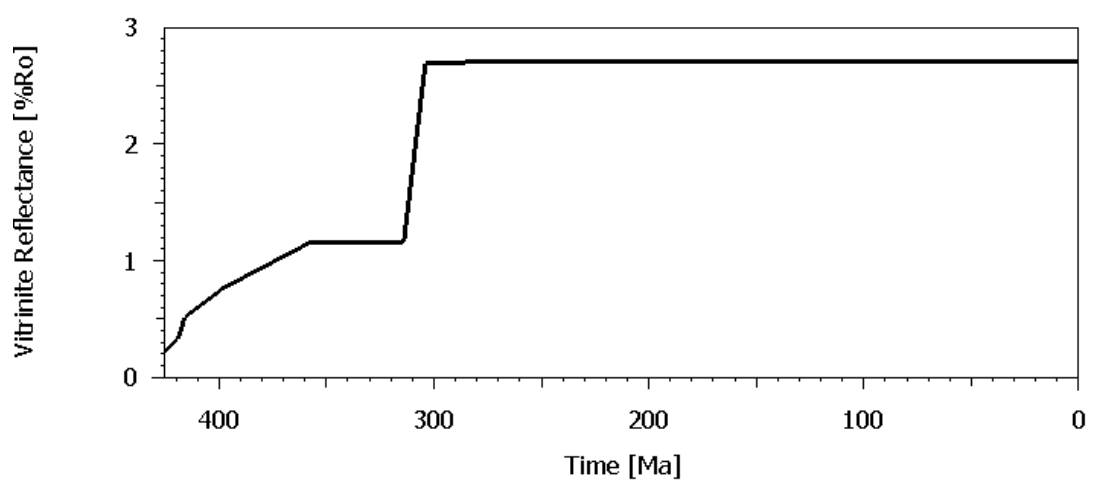

Fig. 4. Evolution of organic matter maturity in vitrinite reflectance scale evolution in the Wenlock source rocks in the Lopiennik IG-1 well

Average present-day organic carbon contents is $1.2-1.3 \mathrm{wt} \%$ in the Wenlock source rocks. Taking into account geochemical data $[2,4,6]$, the following kerogen parameters were assumed in modeling in the analyzed source rocks: kerogen type II, initial TOC $2.0 \mathrm{wt} . \%$, and Hydrogen Index $500 \mathrm{mg}$ hydrocarbons per gram TOC. Calculated kerogen transformation ratio increased significantly in Devonian period and totally reaches over $99 \%$ by the end of Late Carboniferous (Fig. 5). The hydrocarbon generation was developed in the Devonian and Late Carboniferous periods, reaching ca. 1.2 million tons per $\mathrm{km} 2$ of source rock. Petroleum generation was accompanied by a rapid expulsion of hydrocarbons (Fig. 6).

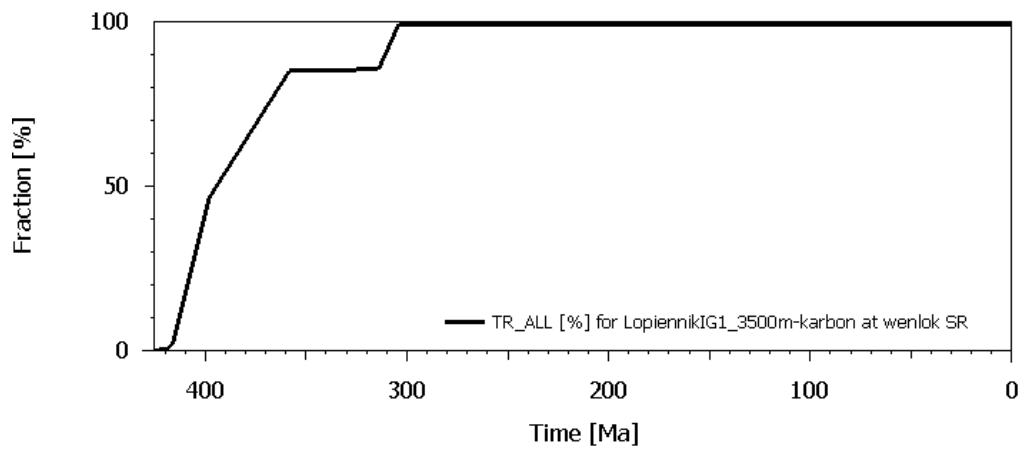

Fig. 5. Evolution of the kerogen transformation ratio in the Wenlock source rocks in the Łopiennik IG-1 well using preferred model (3500m eroded Carboniferous sediments)

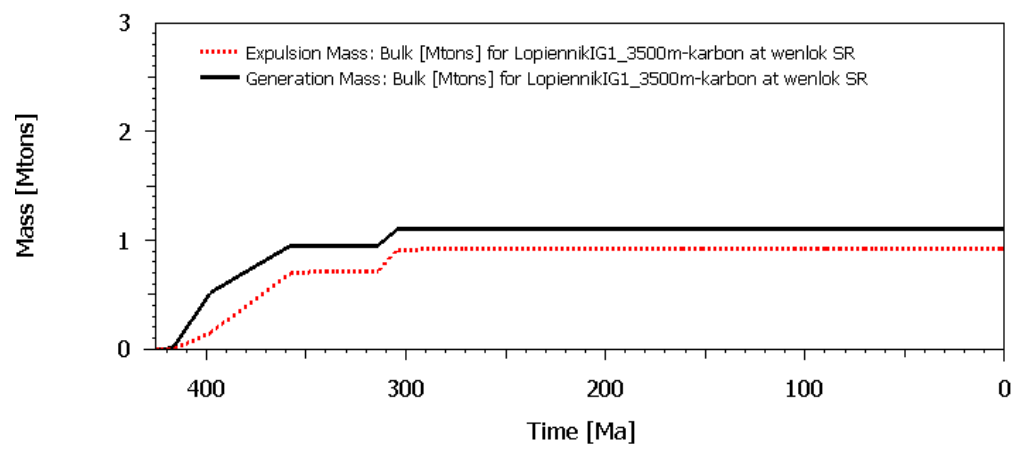

Fig. 6. Petroleum generation and expulsion in the Wenlock source rocks in Lopiennik IG-1 well 


\section{Conclusions}

In the Lower Paleozoic strata of the study area maximum temperature occurred in the Late Carboniferous time. Accomplished tectono-thermal model allowed establishing that petroleum generation in the Lower Silurian source rocks developed in Devonian and Carboniferous periods, reaching the maximum in the Late Carboniferous time. Whereas, during Mesozoic burial, hydrocarbon generation processes did not develop again. Generated hydrocarbons were expelled rapidly from source rocks.

\section{Acknowledgements}

This research has been financially supported by the Polish National Centre for Research and Development (NCRD) grant under the BLUE GAS - Polish Shale Gas program - BG1/GAZGEOLMOD/13. I would like to express my gratitude to the reviewers (Dr. Júlia Kotulová, Dr. Yuriy Koltun and Dr. Pawel Kosakowski) for their valuable input, which significantly improved the quality of the paper.

\section{References}

1. J. Nawrocki, P. Poprawa, Geological Quarterly, 50, 59-76 (2006)

2. P. Poprawa, Przegl. Geol., 58, 226-249 (2010)

3. S.J. Porębski, W. Prugar, J. Zacharski, Przegl. Geol., 61, 468-477 (2013)

4. T. Podhalańska, M.I. Waksmundzka, A. Becker, J. Roszkowska-Remin, I. Dyrka, A. Feldman-Olszewska, A. Głuszyński, I. Grotek, M. Janas, P. Karcz, G. Nowak, J. Pacześna, M. Roman, M. Sikorska-Jaworowska, M. Kuberska, A. Kozłowska, K. Sobień, Przegl. Geol., 64, 1008-1021 (2016)

5. I. Grotek, Przegl. Geol., 64, 1000-1004 (2016)

6. P. Karcz, M. Janas, Przegl. Geol., 64, 995-999 (2016)

7. M., Narkiewicz, Geological Quarterly, 51, 231-256 (2007)

8. P. Krzywiec, Ł. Gągała, S. Mazur, Ł. Słonka, M. Kufrasa, M. Malinowski, K. Pietsch, J. Golonka, Tectonophysics, 713, doi: 10.1016/j.tecto.2017.06.008 (2017)

9. M. Narkiewicz, A. Maksym, M. Malinowski, M. Grad, A., Guterch, Z., Petecki, J. Probulski, T. Janik, M. Majdański, P., Środa, W., Czuba, E., Gaczyński, L., Jankowski, International Journal of Earth Sciences, 104, 775-796 (2015)

10. D. Botor, D.B. Papiernik, T. Maćkowski, B. Reicher, P. Kosakowski, G. Machowski, W. Górecki, Annales Societatis Geologorum Poloniae, 83, 353-383 (2013)

11. J.J. Sweeney, A.K. Burnham AAPG Bulletin, 74, 1559-1570 (1990)

12. J. Pacześna, (red.) Profile głębokich otworów wiertniczych, Państwowego Instytutu Geologicznego - Łopiennik IG-1, 123, (2008)

13. H.I. Petersen, N.H. Schovsbo, A.T. Nielsen, 2013. International Journal of Coal Geology 114, $1-18$

14. D. Botor, J. Golonka, I. Dunkl, A. Anczkiewicz, Tectonophysics (to be published 2017)

15. D. Botor, D.M. Kotarba, P. Kosakowski, Organic Geochemistry, 33, 461-476 (2002) 